\title{
Mariola Nawrocka
}

Biblioteka Główna

Wojskowa Akademia Techniczna w Warszawie e-mail: mariola.nawrocka@wat.edu.pl

(D) https://orcid.org/0000-0003-1652-4549

\section{Iwona Piwońska}

Biblioteka Główna

Wojskowa Akademia Techniczna w Warszawie e-mail: iwona.piwonska@wat.edu.pl

(D) https://orcid.org/0000-0002-5460-3734

\section{Seminarium PolBiT „Social media jako element komunikacji i marketingu w bibliotekach akademickich" (Warszawa, 26 marca 2019 r.)}

26 marca 2019 r. w Bibliotece Głównej Wojskowej Akademii Technicznej w Warszawie odbyło się seminarium PolBiT na temat „Social media jako element komunikacji i marketingu w bibliotekach akademickich". Organizatorem wydarzenia była Biblioteka Główna Wojskowej Akademii Technicznej w Warszawie. Patronat medialny objęła Elektroniczna Biblioteka: portal bibliotekarzy i pracowników informacji (EBIB).

Spotkania grupy PolBiT stanowią przykład długotrwałej i owocnej współpracy polskich bibliotek technicznych. Zostały zapoczątkowane przez Bibliotekę Główną Politechniki Warszawskiej i są systematycznie organizowane także przez inne biblioteki. W założeniu mają służyć wymianie doświadczeń, a także poszukiwaniu sposobów realizacji nowych zadań i rozwiązywaniu różnych kwestii związanych z zawodem bibliotekarza akademickiego. Seminaria grupy PolBiT mają roboczą formę, w ich trakcie przedstawiciele środowiska dzielą się praktyczną 
wiedzą, przedstawiają nowe pomysły, wdrożone rozwiązania i odniesione sukcesy.

Biblioteki akademickie coraz częściej postrzegane są jako nowoczesne ośrodki informacyjne, miejsca wspomagające naukę, w których bibliotekarze często wykorzystują interaktywne technologie i media społecznościowe do kontaktu z użytkownikami. To głównie dzięki social mediom biblioteka ma $\mathrm{z}$ nimi stały kontakt, co wpływa $\mathrm{z}$ kolei na zamieszczane treści, takie jak aktualne wydarzenia, oferty, spotkania itd.

Tegoroczne seminarium poświęcone było następującym zagadnieniom:

- rodzaje social mediów wykorzystywanych w bibliotekach akademickich;

- funkcje social mediów w bibliotekach akademickich;

- social media jako rodzaj marketingu bibliotecznego;

- wpływ social mediów na wizerunek biblioteki akademickiej;

- różnorodna oferta bibliotek akademickich w social mediach;

- co wpływa na aktywność bibliotek akademickich w social mediach?

Uczestników seminarium powitała Bogumiła Konieczny-Rozenfeld, dyrektor Biblioteki Głównej Wojskowej Akademii Technicznej w Warszawie. Słowo wstępne wygłosili prorektor ds. naukowych Krzysztof Czupryński i przewodniczący Rady Bibliotecznej Marek Kojdecki, którzy podkreślali rolę biblioteki w środowisku akademickim oraz znaczenie social mediów w kontaktach z użytkownikami bibliotek akademickich.

Seminarium adresowane do pracowników bibliotek technicznych, którzy zajmują się mediami społecznościowymi, ze względu na nośną tematykę spotkało się z dużym zainteresowaniem. W spotkaniu udział wzięło 75 uczestników z 23 instytucji. Wystąpienia zostały zaprezentowane podczas dwóch sesji.

Pierwszy referat, Facebook, Instagram, Wikipedia w Bibliotece Politechniki Lubelskiej, wygłosili Paulina Artymiuk-Broda i Łukasz Tomczak z Biblioteki Politechniki Lubelskiej. Prelegenci omówili m.in. charakterystyczne cechy social mediów, takie jak: dostępność, użyteczność i natychmiastowość. Według nich jednym z głównych celów korzystania z social mediów w bibliotekach akademickich jest przede wszystkim obecność w tych mediach, w których aktywni są użytkownicy. Dzięki temu media społecznościowe można wykorzystać w takich obszarach, jak: marketing, obsługa użytkownika, komunikacja, budowanie wizerunku biblioteki. Dodatkowo social media, są łatwe w użyciu i wolne od kosztów.

W kolejnej prezentacji, $\# B U W$, czyli o Bibliotece Uniwersyteckiej $w$ Warszawie $w$ mediach społecznościowych, prelegentki z Bibliote- 
ki Uniwersyteckiej w Warszawie: Anna Białanowicz-Biernat, Dorota Bocian, Maja Bogajczyk, Anna Książczak-Gronowska, w interesujący sposób przybliżyły swoje doświadczenia z social mediami. Prelegentki z Biblioteki Uniwersyteckiej w Warszawie jako główne strategie publikowania przyjęły promocję wydarzeń, zbiorów, usług oraz kontakt $\mathrm{z}$ użytkownikiem. Zaprezentowały najciekawsze przykłady wydarzeń publikowanych na Facebooku, Instagramie i Blogu (BuwLOG).

Agnieszka Jancewicz z Biblioteki Politechniki Białostockiej, autorka wystąpienia Social media w Bibliotece Politechniki Białostockiej, opowiedziała o tym, w jaki sposób przeprowadzka do nowego, atrakcyjnego architektonicznie budynku zmobilizowała pracowników do większego zaangażowania się $\mathrm{w}$ promocję Biblioteki, również poprzez media społecznościowe.

Wystąpienie zamykające pierwszą sesję przygotowali przedstawiciele organizatorów. Dominika Górska i Rafał Łojewski w prezentacji Social media w Bibliotece Głównej WAT na tle wybranych wojskowych bibliotek akademickich $w$ Polsce, omówili specyfikę prowadzenia mediów społecznościowych w bibliotekach uczelni wojskowych. Chodzi o szczególną grupę odbiorców, studentów wojskowych realizujących jednocześnie dwa programy nauczania. Kontakt z Biblioteką mają oni często jedynie poprzez social media.

Drugą sesję rozpoczęły przedstawicielki Biblioteki Głównej Politechniki Warszawskiej: Justyna Antosik-Tylkowska, Magdalena Maciąg, Monika Matera-Łabęda, Iwona Moroń-Chmielarska, Agnieszka Nejman, Emilia Nowakowska, Ewelina Sadkowska i Edyta Strzelczyk. W wystąpieniu Jak przyciagnać uwage użytkowników w mediach spotecznościowych? Wyzwania i trudności (z doświadczeń $B G P W$ ) prelegentki wskazały trudności wynikające z prowadzenia social mediów, takie jak: określenie celów, ustalenie strategii działania, wyznaczenie grupy odbiorców. Przedstawiając strategię działań, położyły nacisk na przekazywanie informacji o działalności Biblioteki, jej zasobach, usługach, a także budowanie pozytywnego wizerunku. W dalszej części prezentacji przywołały najczęściej wybierane przez użytkowników posty, treści zamieszczane na Facebooku, Instagramie i Blogu (Blog BGPW), a także ich zasięg i aktywność.

Tematem rozważań Urszuli Szybowskiej z Biblioteki Politechniki Gdańskiej w wystąpieniu pt. Media społecznościowe a kształtowanie wizerunku biblioteki akademickiej był idealny wizerunek biblioteki akademickiej, kreowany poprzez usługi, narzędzia, działania promocyjne, przestrzeń. Czy istnieje uniwersalna recepta na media społecznościowe? $\mathrm{W}$ podsumowaniu interesującego wystąpienia prelegentka stwierdziła, 
że media społecznościowe $\mathrm{z}$ pewnością mogą być częścią procesu budowania pozytywnego wizerunku biblioteki akademickiej oraz że komunikacja poprzez te media może mieć pozytywny wpływ na jakość usług edukacyjnych biblioteki uczelnianej.

W kolejnym wystąpieniu, Akademickie biblioteki teologiczne w mediach społecznościowych, Anna Seweryn z Instytutu Bibliotekoznawstwa i Informacji Naukowej Uniwersytetu Śląskiego w Katowicach omówiła funkcjonowanie akademickich bibliotek teologicznych w mediach społecznościowych. W swych badaniach uwzględniła polskie szkoły wyższe kształcące w zakresie teologii, w tym publiczne uczelnie akademickie, uczelnie kościelne katolickie i uczelnie kościelne niekatolickie. Według autorki niewielkie wykorzystanie potencjału mediów społecznościowych może wynikać ze specyfiki omawianych bibliotek. $\mathrm{W}$ podsumowaniu podkreśliła, że ważnym kanałem komunikacji bibliotek teologicznych jest profil na Facebooku aktywnie prowadzony przez Federację Bibliotek Kościelnych FIDES, jednak, zdaniem prelegentki, $\mathrm{w}$ większym stopniu służy on do wymiany informacji między profesjonalistami niż do komunikacji z użytkownikami.

Referat zamykający seminarium, Dlaczego nie Twitter? Wykorzystanie mikroblogingu $w$ działalności bibliotek akademickich $w$ Polsce, wygłosiła Katarzyna Bikowska z Uniwersytetu Warmińsko-Mazurskiego w Olsztynie. Autorka starała się ustalić przyczyny sporadycznego wykorzystania mikroblogingu przez biblioteki akademickie w Polsce. Podkreśliła, że aby osiągnąć pozytywne wyniki i być zauważonym w sieci, należy w odpowiedni sposób posługiwać się mediami społecznościowymi, dobrze poznać ich funkcje, odbiorców, formę i język.

Podczas kończącej spotkanie dyskusji uczestnicy seminarium podzielili się swoimi doświadczeniami i sposobami prowadzenia social mediów w rodzimych bibliotekach. Rozmawiali o poruszanych przez referentów kwestiach. Akcentowali fakt, że prowadzenie mediów społecznościowych przez biblioteki wymaga od bibliotekarzy kreatywności i wiedzy.

Zgodnie uznali, że najważniejszą kwestią dotyczącą social mediów w bibliotekach akademickich jest odpowiedź na pytanie, jak nimi zarządzać, aby jak najlepiej spełniały funkcje komunikacyjne, marketingowe i promocyjne.

$\mathrm{Na}$ stronie Biblioteki Głównej Wojskowej Akademii Technicznej (http://www.bg.wat.edu.pl), w zakładce POLBIT zostały zamieszczone prezentacje przesłane przez uczestników spotkania. 